\title{
Investigating vertical social media impact through influencer on risky sexual behavior among adolescents in Indonesia
}

\author{
Raidah Intizar Yusuf \\ Communication Sciences Study Program, Faculty of Social and Political Sciences, \\ Universitas Islam Makassar, Indonesia \\ Email: raidahintizar.dty@uim-makassar.ac.id
}

\begin{abstract}
Social media has been identified as a factor in adolescents' adoption of risky sexual behavior. This research is here to answer whether social media has a vertical effect on adopting risky sexual behavior, given the increasing number of influencers on the platform. We sought the connection of whether influencers can influence the dating standards of adolescents, which will end up contributing to the adoption of risky sexual behavior. As risky sexual behavior is becoming more prevalent in Makassar, we picked Makassar adolescents as our study object. We also compared urban and rural by including Maros adolescents. Data were collected with an online survey. Four surveyors are employed to find targeted respondents: youth in their 15-18 years old. Respondents filled out an online questionnaire from September 7, 2020, to September 14, 2020. As many as 313 responses were valid, 50.5 percent of the respondents were domiciled in Makassar, and the remaining 49.5 percent came from Maros. Two out of three respondents are women (63.3 percent). A series of independent t-tests, and Andy F Hayes PROCESS scheme, were used to analyze the data. The independent $t$-test results showed that male urban adolescents are more likely to exhibit risky sexual behavior. The central hypothesis test results showed
\end{abstract}


that social media influencers indirectly affect risky sexual behavior mediated by adolescent dating styles, answering the study's initial assumption.

Keywords: Social Media Influencer, Risky Sexual Behavior, Adolescent

\section{INTRODUCTION}

Based on a data release from we are social and Hootsuite in the Digital 2020 report, internet penetration in Indonesia has reached 64 percent of the 271.1 million population. As many as 160 million people are reported to have social media accounts; adolescents, or those aged 13-24, have become one of Indonesia's most significant social media users (we are social \& Hootsuite, 2020). The data is supported by a survey in 2017 , which showed that out of four adolescents aged 13-18 years, three of whom accessed the internet. During the Covid-19 pandemic, it is difficult to imagine that this penetration rate will drop with the implementation of school from home.

Several phenomenons show that it is easier to find risky sexual behavior exhibitions among adolescents as society becomes more digital. An infographic provided by Katadata.com in 2021 reveals that in the plague year, there has been a surge in the application of dispensations for early marriage at the religious court across Indonesia, with Kalimantan and Sulawesi being the two highest number of applicants, respectively. There are 34.000 applications registered in 2020 and a 97 percent chance of being granted, compared to 23.700 applications in 2019 and less than half the chance of fulfillment. Clerks and experts clarify that most of the reasons for filing the dispensation were pregnancy outside of marriage (Wedya, 2020; Kasih, 2020). Interestingly, BPS data shows that Kalimantan and Sulawesi have the highest child marriage rate in Indonesia (Al-Anshori, 2020).

The dispensation application was in line with a result of previous research conducted by the Central Bureau of Statistics (BPS), the National Development Planning Agency (Bappenas), UNICEF, and the Center for Research and Advocacy for the Protection and Quality of Life of Children at the University of Indonesia (PUSKAPA). The "Prevention of Child Marriage: An Acceleration that Cannot be Delayed" report reveals that in the case of child marriage, Indonesia ranks first in the world based on 2018 data where 1,220,900 women aged 20-24 years reported being married before the age of 18 (Unicef, PUSKAPA, Bappenas, \& BPS, 2020). 
Unwanted pregnancy is one of the consequences of adolescents' risky behavior, ending in early marriage. Based on PKBI data (Handayani, 2011), it is revealed that 15 percent of adolescents aged 10-24 years have had sex outside of marriage due to high curiosity about sex; this has led to unwanted pregnancies. Parents who were devastated by their children deviation, marrying these children off as a shortcut. Early marriage itself is believed to cause a systematic collapse systemic collapse of a child's well-being.

Apart from early marriage, risky behavior can also lead to the spread of sexually transmitted diseases; sexually transmitted infections are still a problem globally and locally (Prajagopta, 2019). A disheartening fact was revealed in the research of Dr. Leo Prawirodihardjo's dissertation, which conducted a study entitled "Adolescent Free Sex Behavior in Makassar City." Prawirodihardjo revealed that Makassar City, as a metropolitan city, is increasingly prevalent with free sex behavior, nearly 4,000 people with AIDS in South Sulawesi, around 3,134 sufferers, or about 80 percent are in Makassar City. Makassar city is in the top three cities with people living with HIV/AIDS in Indonesia, after Jayapura and Jakarta (KSR PMI Unhas, 2017).

Several studies assume (Waheed, 2019; Festi \& Quandt, 2020; Febriani \& Ranakusuma, 2020; Mulya, Lukman, \& Yani, 2020) that internet use has a role in increasing risky sexual behavior in adolescents. Instant access without parental supervision to the internet will expose adolescents to content shaping a particular lifestyle. According to the WHO definition, adolescents, especially early adolescents, are most likely to be vulnerable because their capacity is still developing. Still, they naturally explore outside their families; and with the presence of the internet and social media, exploration outside family relationships is now easier for them.

The diversity of social media allows a person on the internet to have multiple accounts. The content circulating in cyberspace is very abundant, ranging from text, photos, videos with a short duration, such as those on Instastory and Tik-Tok videos, to long-duration videos like Youtube. From the horizontal counterparts, adolescents are confronted with peer-to-peer contents that can trigger them to do the same action; as discussed by (Festi \& Quandt, 2020), on a global scale, peers influence adolescents in getting into risky online behavior. Additionally, Istiaisyah Amiyni (2017) also proves that risky sexual behavior is caused by the minimal role of parents, exposure to mass media, and peer factors. 
Interestingly, the vertical effect of social media is missing from the specific discussion, namely how social media celebrities influence adolescents. With social media, celebrities can spread their lifestyle by uploading directly through their accounts without filters and duration restrictions as if through mass media. The term "goals" is mentioned by followers when commenting on celebrity content to express their desire to have a similar life to these celebrities; this raises a question: Do celebrities or their content, directly and indirectly, affect the adoption of risky sexual behavior? Unfortunately, research on celebrities' role on social media in shaping risky sexual behavior is still limited. Meanwhile, over time, studies on the role of social media influencers in shaping particular lifestyle have become increasingly important.

Based on the background above, this research comes with several objectives. The first objective is to determine the differences in urban and rural adolescents (objective 1a), followed by differences in gender categories (objective $1 b)$ in the social media influencer variables, relationship style, and risky sexual behavior. The second objective is the primary objective of this study, i.e., to determine whether social media influencers have a direct role (objective 2a) and an indirect role mediated by adolescent relationship style (objective $2 \mathrm{~b}$ ) on adolescent risky sexual behavior.

From the results of this study, the researcher expects to identify whether an influencer influences adolescent sexual risk behavior, either directly or indirectly, to provide a meaningful recommendation for decision-makers and provide solutions in preventing the adoption of risky sexual behavior. Demographic mapping can also help provide targeted solutions.

\section{LITERATURE REVIEW}

\section{Risky Sexual Behavior and Social Media}

The massive use of social media has resulted in changes in several aspects of human life. As the largest group of social media users (we are social \& Hootsuite, 2020), adolescents aged 13-24 years are the most likely to use social media in various ad-hoc ways. The pandemic will further strengthen the role of social media in the lives of adolescents.

Before the advent of social media, mass media became one of the spreaders of the metropolis' lifestyle. A few years ago, one of the causes of adopting risky sexual behavior was mass media (Amiyni, 2017). Television, as 
an example, has become a commercial media that fulfills what the audience wants. The results of a previous study (Nelissen, Beullens, Lemal, \& Bulck, 2015) show that television has been a significant negative predictor of a healthy lifestyle. The study discovered that the higher the intensity of a person watching television, the less healthy the lifestyle one would have.

The emergence of the internet presents a new challenge; if previously mass media was owned by groups, such as television, which one family in one household could access, the rapid internet development made the device owned personally. Now someone can quickly get information through a device the size of a palm. Also, in the beginning, people used mobile devices with internet access for specific needs such as information and communication. Nowadays, people would entertain themself with content from the internet. In addition, the personal nature of internet devices causes access to information has becoming on-demand; for example, adolescents only access the information they want to access, including information that can satisfy their curiosity; this can lead to risky sexual behavior. The fact is supported by Lailatul Fitriyah's (2016) research, which underlines external and internal factors in the adolescent that could cause risky sexual behavior. Internal factors are the most neglected factors in dealing with risky sexual behavior, i.e., the nature of experimentation in adolescence.

In a study (Hidayaningsih, 2014), it was found that adolescents marry at a young age due to pregnancy before marriage, not going to school, and customs that apply matchmaking for socio-economic attributes. Many adolescents admit that casual sex is a common way to seek pleasure; the behavior of watching videos or viewing adult sites is also considered normal. Subsequent research from Istiaisyah Amiyni (Amiyni, 2017) revealed that several factors that cause adolescent risky sexual behavior are exposure to mass media, parents' role, and peer factors. In this digital era, the peer factor can be found in social media, given that social media connects youth.

The use of social media by adolescents has been pointed out to be the cause of adolescents' moral degradation. High curiosity (Fitriyah, 2016; Waheed, 2019), combined with tools that can be accessed personally without parental supervision, can trigger risky online behavior (Febriani \& Ranakusuma, 2020). In that study (Idem, 2020), it was found that parental supervision affected adolescents' risky online behavior. Likewise, a study conducted by Adele Prima Mulya, Mamat Lukman, and Desy Indra Yani (2020) linked the correlation between adolescent sexual behavior with the media and the role of parents. 
A global study also emphasized that using digital media is generally prominent for early adolescents; these risks include cyberbullying, online addiction, and sexting (Festi \& Quandt, 2020). More specifically on risky sexual behavior, a meta-analysis of 67,407 adolescent respondents (Vannucci, G. Simpson, Gagnon, \& Ohannessian, 2020) explained that there was a slight positive relationship between social media use and risky sexual behavior $(r$ $=0.21,95 \% \mathrm{CI}=0.15-0.28)$. Still, there was a more significant effect in the younger sample when explicitly discussing the effect of social media use on risky sexual behavior.

\section{Social Media Influencers and Lifestyle}

As a form of information and communication technology development, social media has led to what is known as the era of disruption. The disruption era is a situation where the industrial world's movement or job competition is no longer linear; it changes rapidly, fundamentally, and disrupts conventional patterns to create new orders (Rizal, 2017).

One of the significant changes brought about by the disruption era is how companies can access consumers' data through social media. The fact completely changes the marketing strategy as it becomes more straightforward for companies to know what media users want. In the long run, marketing for the capitalist lifestyle can be instilled in social media users. Not to mention eWOM (electronic-Word of Mouth) that has made the information about a product reach potential buyers easily (Baharuddin \& Yaacob, 2020; Rai \& Tripathi, 2020). Potential buyers could also access the marketplace through applications conveniently.

As part of marketing strategy, social media influencers are one of the new roles that have emerged from the era of disruption. People who are popular on social media, both television celebrities to exclusive social media celebrities, have become a new approach for a company to market its products; this phenomenon is known as an endorsement. Not only companies but the government can also use influencer services to amplify an idea.

There are four requirements for an account to be verified, i.e., authentic, unique, have a complete and well-known profile. However, fame is the most crucial aspect; as Connoly (2017) discussed, many followers make a person an influencer. This high number certainly speaks of many things, one of which is influence; a study (Idem, 2017) had proven that most followers of social media influencers do follow their idol's lifestyle. 
Each influencer has a specific market niche that can invite individual followers according to the influencer's content trend. Some influencers focus on discussing food; some discuss traveling; some discuss religion, lifestyle, and much other unique content. The specifications of these influencers make it easier for companies to offer endorsements. Lifestyle displayed by influencers, such as traveling to certain places, eating at certain restaurants, watching movies in theaters, using specific products, has been proven to lead consumers to do the same, or in other words, adopt the influencer lifestyle. The relationship between influencers and follower trust, lifestyle adoption, and increased sales has been studied by several studies (Karouw, Worang, \& Pandowo, 2019; Jin, Muqaddam, \& Ryu, 2019; Zhang, Lin, \& Goh, 2018).

Knowing that social media influencers have impacts on their followers and that social media generally increases risky sexual behavior in adolescents, do social media influencers contribute to the variable? Furthermore, how are their roles? Is it an indirect or direct role?

Based on the studies above, provisional assumptions were being prepared to answer the research objectives.

The first objective is to determine the differences in adolescents in urban and rural areas (objective 1a), followed by differences in gender categories (objective 1b) in social media influencer variables, dating style, and risky sexual behavior. Given the massive internet penetration among adolescents and that rural areas such as Kalimantan have the highest early marriage (Unicef, PUSKAPA, Bappenas, \& BPS, 2020), the presumption for objective 1a is to support the null hypothesis.

H1a: There are no significant differences based on the area in the three variables tested in this study.

Furthermore, based on gender, very few studies have compared the differences between the sexes in terms of risky sexual behavior, so this study has conjectures to support the null hypothesis.

H1b: There are no significant differences based on gender in the three variables tested in this study

The second objective of this study, and is the main objective, is to determine whether social media influencers have a direct role (objective 2a) and an indirect role (objective 2b) on adolescent risky sexual behavior moderated by teenage lifestyle. Previous research did not specifically discuss the role of social media influencers, so there was no preliminary data to find out that influencers 
directly affected risky sexual behavior, so the presumption for purpose $2 \mathrm{a}$ supported the null hypothesis.

H2a: There is no significant direct effect of social media influencers on risky sexual behavior.

As for goal 2b, Connoly (2017) has proven that adolescents follow their idols' lifestyle, so this study presumes to reject the null hypothesis.

$\mathrm{H} 2 \mathrm{~b}$ : There is an indirect effect of influencers on risky sexual behavior mediated by the relationship style.

\section{METHODS}

The research method in this study uses a quantitative approach; an online survey collects data. Four surveyors are employed to find a minimum of one hundred respondents each. Respondents filled out an online questionnaire from September 7, 2020, to September 14, 2020. This study's target was adolescents aged 15-18 years; there are among Indonesia's most prominent internet users based on a field survey conducted by APJII (Association of Indonesian Internet Service Providers) in March-April 2019 and among early adolescents. Target respondents were predominantly in Makassar. The researcher selected the city based on Dr. Leo Prawirodihardjo's dissertation research, which revealed that Makassar is among the top three cities with people living with HIV/AIDS in Indonesia, after Jayapura and Jakarta (KSR PMI Unhas, 2017). The neighboring district of Makassar, Maros, was included in the analysis to see any differences between urban and rural population.

As many as 313 responses were valid and filled out the online survey thoroughly, 50.5 of which live in the city of Makassar $(N=158)$, and the remaining 49.5 percent came from Maros $(N=155)$. As many as 63.3 percent of respondents were women $(N=198), 34.2$ percent $(N=107)$ were men, 2.6 percent of respondents chose not to answer gender questions.

There are several sections in the online survey; the first section is the introductory research section, followed by confirmation of age and domicile. Furthermore, respondents confront randomized questions between relationship style and risky sexual behavior; this is done to avoid the respondent's confounding effect. Relationship style variable includes statements rated on a Likert scale of five points from Strongly disagree to Strongly agree on statements as follows: traveling out of town; watching movies together, eating out together, 
and going out together $(M=2.74, S D=1.14, \alpha=.89)$. Furthermore, the risky sexual behavior variable asks the reasonableness of the contact in the premarital relationship, i.e., holding hands, hugging, kissing, and having sex ( $M=1.67$, SD $=.81, \alpha=.81$ ).

Several statements were then displayed, which were rated on a five-point Likert scale Strongly disagree-Strongly agree, namely 1) I find influencer life interesting to know, 2) I feel it is important to know what influencers think about something, and 3) The influencers' life can become "GOALS " for me or my ideals. This variable is called the social media influencer scale $(M=3.41$, $S D=.99, \alpha=.84$ )

The researchers determined the number of independent variables, namely demographics and the scale of social media influencers, to answer the research question. The mediator variable is the relationship style, and the dependent variable is the risky sexual behavior variable.

Data analysis uses several analyzes. The first is the independent t-test analysis, where three variables are included in the hypothesis test to see significant differences between urban and rural adolescents and differences in boys and girls. Next is Andy F Hayes' PROCESS scheme by activating the mediator mode to determine the predictor variable's indirect effect on the outcome variable.

\section{RESULTS AND DISCUSSION}

\section{Results}

This study aims to provide meaningful recommendations in overcoming risky sexual behavior among adolescents. This meaningful recommendation can be achieved by answering several sub-objectives of this study. The first question is regarding the domicile of adolescents. The domicile category is explored to determine whether there are significant differences based on residence, whether adolescents in rural areas display a relationship style and risky behavior that tends to be lower than adolescents in urban areas and vice versa.

This study's initial assumption is that there are no significant differences among adolescents in urban and rural areas. Differences should not be found in the three variables that include dating style, risky sexual behavior, and social media influencers; or in other words, this study supports the null hypothesis. The results of the hypothesis test using a set of independent t-tests can be observed in table 1 . 
Informasi, Vol. 51. No. 2. (2021), 327-344

Table 1. Urban vs. Rural Means, standard deviations, and independent t-test results

\begin{tabular}{|c|c|c|c|c|c|c|c|c|}
\hline \multirow[t]{2}{*}{ Total sample } & & & & \multicolumn{2}{|c|}{ Urban } & \multicolumn{2}{|c|}{ Rural } & \multirow{2}{*}{$\begin{array}{l}\text { Independent } \\
\text { sample t-test } \\
\text { P-value }\end{array}$} \\
\hline & $\mathrm{N}$ & $\mathrm{M}$ & $\mathrm{SD}$ & $\mathrm{M}$ & $\mathrm{SD}$ & $\mathrm{M}$ & $\mathrm{SD}$ & \\
\hline $\begin{array}{l}\text { Relationship } \\
\text { style }\end{array}$ & 313 & 2.74 & 1.14 & 2.87 & 1.10 & 2.61 & 1.16 & $<.05$ \\
\hline Risky behavior & 313 & 1.67 & .81 & 1.76 & .85 & 1.57 & .75 & $<.05$ \\
\hline $\begin{array}{l}\text { Social media } \\
\text { influencer }\end{array}$ & 310 & 3.41 & .99 & 3.39 & 1.00 & 3.41 & .99 & .882 \\
\hline
\end{tabular}

The independent t-test shows significant differences in the mean relationship style and risky sexual behavior, which indicates that adolescents who live in Makassar (representing urban areas) tend to be significantly higher in terms of dating style, and risky sexual behavior. Thus, this study's first hypothesis is not proven as there are significant differences, i.e., relationship style and risky sexual behavior, so the null hypothesis is rejected.

Meanwhile, significant differences are also found in each variable's gender category, as observed in table 2.

Table 2. Females vs. Males Means, standard deviations, and independent t-test results

\begin{tabular}{lllllllll}
\hline Total sample & & & & Females & Males & $\begin{array}{l}\text { Independent } \\
\text { sample t-test }\end{array}$ \\
\hline & $\mathrm{N}$ & $\mathrm{M}$ & $\mathrm{SD}$ & $\mathrm{M}$ & $\mathrm{SD}$ & $\mathrm{M}$ & $\mathrm{SD}$ & P-value \\
\hline $\begin{array}{l}\text { Relationship } \\
\text { style }\end{array}$ & 305 & 2.74 & 1.14 & 2.51 & 1.11 & 3.17 & 1.06 & $<.001$ \\
\hline Risky behavior & 305 & 1.67 & .81 & 1.47 & .56 & 2.03 & 1.05 & $<.001$ \\
\hline $\begin{array}{l}\text { Social media } \\
\text { influencer }\end{array}$ & 302 & 3.41 & .99 & 3.25 & .98 & 3.70 & .98 & $<.001$ \\
\hline
\end{tabular}

The total sample based on gender in this study was predominantly women $(N=198)$, and 34.2 percent $(N=107)$ were men. Eight respondents chose not to answer gender questions or 2, 6 percent. In the table above, it can be observed that males are significantly higher than females for each variable. 
So the hypothesis $2 \mathrm{~b}$ in this study, which supports the null hypothesis, is also rejected. There are significant differences in each of the variables tested, including relationship style, risky sexual behavior, and social media influencers. The male respondents in this study, although the number was smaller than the female respondents, showed a significant difference.

Before testing the following essential hypothesis, several assumptions needed to be met, the researcher carried out a multicollinearity analysis by consulting the VIF number. It was found that there was no indication of multicollinearity in both cases. Furthermore, the outliers were analyzed using the boxplot; several suspected outliers in the risky behavior and social media use variables. However, the outliers did not significantly impact the results after seeing the $5 \%$ trimmed mean, which was not much different from the total sample mean, so this result still involved the suspected outliers.

Researchers' primary assumption is an indirect effect of social media influencers on risky sexual behavior, mediated by the relationship style. The relationship style is placed as a mediator variable. The social media influencers variable is a predictor of risky sexual behavior; this departs from the assumption that there is an indirect effect of social media influencers on risky sexual behavior; social media influencers increase adolescents' relationship style, which will increase their risky sexual behavior. The main hypotheses to be tested are as follows.

H2a: There is no significant direct effect of social media influencers on risky sexual behavior.

H2b: Social media influencers' indirect effect on risky sexual behavior mediated by the relationship style.

The hypothesis was tested using the PROCESS scheme by Andy F Hayes. The following are the results of the analysis output.

\section{Figure 1}




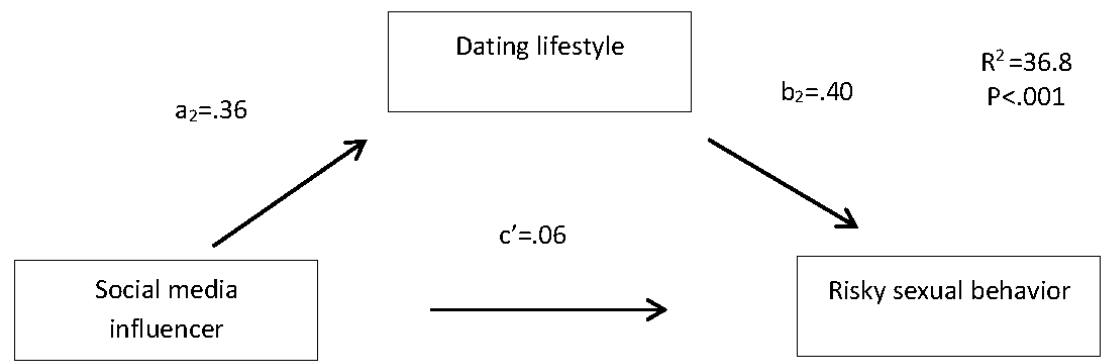

Figure 1. Mediation model of social media influencer and risky behavior

Social media influencers' direct effect on risky sexual behavior was .06, and this direct effect was not significant $(p=.087)$. Conversely, a significant indirect effect of using social media influencers on risky behavior is 0.15 (95\% CI .096; .214). The result means that one additional unit of social media influencers will increase by .15 of risky sexual behavior. There is a significant interaction between social media influencers and relationship style.

Table 3 Output of the mediation analysis

\begin{tabular}{lllll}
\hline $\begin{array}{l}\text { Indirect } \\
\text { effect }\end{array}$ & $\begin{array}{l}\text { Unstandardized } \\
\text { beta }\end{array}$ & Bootstrap SE & $\begin{array}{l}\text { Bootstrap } \\
\text { 95\%LLCI }\end{array}$ & $\begin{array}{l}\text { Bootstrap } \\
\text { 95\%LLCI }\end{array}$ \\
\hline $\mathrm{a}_{1} \mathrm{~b}_{1}$ & .1508 & .0302 & .0969 & .2141 \\
\hline Direct effect & $\begin{array}{l}\text { Unstandardized } \\
\text { beta }\end{array}$ & SE & P-value & $\begin{array}{l}\text { \# Bootstrap } \\
\text { samples }=1000\end{array}$ \\
\cline { 1 - 3 } c' $^{\prime}$ & .0670 & .0391 & .0875 & \\
\hline
\end{tabular}

Based on the data in table 3, the H2a in this study, which supports the null hypothesis, is proven considering that social media influencers have no direct effect on risky sexual behavior. Also, the analysis results show that $\mathrm{H} 2 \mathrm{~b}$, which rejects the null hypothesis, is also proven in this study; the data show an indirect effect of social media influencers on risky sexual behavior mediated by relationship style.

\section{Discussion}

Social media is a big wave that changes so many orders in human life. Humans communicate, seek information, entertain themselves, and make decisions have changed drastically from five to ten years ago. Adolescents who 
are found in cyberspace are one of the most affected parties by social media. Previous research states that the risk of using the internet is generally prominent for early adolescents (Festi \& Quandt, 2020). Early adolescents are those who instinctively conduct experiments as internal encouragement (Fitriyah, 2016), as well as exploration after leaving the family confinement even though their capacity has not yet fully developed.

In Indonesia, the increasing number of child marriages and sexually transmitted infections in adolescents, especially in Makassar, is the main concentration of experts and is at an alarming stage. Both of these indicate the spread of adolescent risky sexual behavior. This increase is directly proportional to adolescent internet penetration, significantly increasing the number of social media users among adolescents.

Social media influencers are one of the disruptions after social media; the endorsement culture has begun to stick with social media influencers, which is an ad-hoc way for entrepreneurs, as well as the industries to advertise their products. Connolly (2017) proved in his study that most followers follow the lifestyle of social media influencers. These observed behaviors can set a precedent for adolescents following the social media influencer relationship style, which may be the cover of an endorsement, such as watching certain films, eating at certain restaurants, traveling to a particular place. Concerning the effectiveness of endorsements has been studied and proven by several studies in terms of follower trust (Karouw, Worang, \& Pandowo, 2019), lifestyle adoption (Jin, Muqaddam, \& Ryu, 2019), to increase product sales (Zhang, Lin, \& Goh, 2018). The lifestyle adopted by adolescents and later can trigger them to practice risky sexual behavior has been proven in this study. Indeed, social media influencers do not directly affect risky sexual behavior, but their relationship style or dating standards can be adopted by adolescents resulting in risky sexual behavior.

Interestingly, in this study, it was found that there were significant differences between urban adolescents and rural adolescents in the variables of relationship style and risky sexual behavior. Furthermore, significant differences were found in men and women in the three tested variables, i.e., social media influencers, relationship style, and risky sexual behavior. So it can be said that male adolescents who live in urban areas are vulnerable to risky sexual behavior. In paying attention to risky sexual behavior, both males and females must receive proportional treatment. Education regarding a healthy lifestyle, which includes knowledge of sexuality, avoiding the causes of a free lifestyle, could maximize 
reproductive health for both men and women. Adequate reproductive health will affect children born to ready parents, without problems both physically and mentally.

This study underlines that urban male adolescents still need education about reproductive health and the dangers of risky sexual behavior. So far, reproductive health knowledge is focused on girls, while boys also play a vital role. Failure to impart reproductive health knowledge to boys will have a systemic impact for everyone, therefore we encourage policy maker to take our finding into consideration when forming policy for communicating such risks.

\section{CONCLUSION}

A specific research take on social media influencers has become increasingly important as the number of influencers on social media has escalated over time. The study had proven an indirect effect of social media influencers on risky sexual behavior as mediated by relationship style or dating standards. Moreover, the results also emphasized that boys living in cities are more prone to risky sexual behavior. The study results reflect that information dissemination about the danger of risky behavior and reproductive health has been skewed to girls, while both have to be proportionally addressed. We recommend further studies to include more dimensions in their studies, such as parental supervision, reproductive health knowledge, and religious education. We also recommend broadening the population to have a bigger picture of adolescent risky sexual behavior in Indonesia.

\section{ACKNOWLEDGEMENT}

We would like to thank RISTEKBRIN that funded this research, and LPPM UIM as our facilitator, as well as everyone involved.

\section{REFERENCES}

Al-Anshori, A. N. (2020, September 9). Data Badan Pusat Statistik: Angka Pernikahan Dini di Kalimantan Selatan Tertinggi di Indonesia. Retrieved Oktober 12, 2020, from Liputan6.com: https://www.liputan6.com/ health/read/4351605/data-badan-pusat-statistik-angka-pernikahan-dinidi-kalimantan-selatan-tertinggi-di-indonesia 
Amiyni, I. (2017). Faktor-faktor yang berhubungan dengan perilaku seksual beresiko di salah satu SMA Negeri Kota Padang. Universitas Andalas.

Baharuddin, N. A., \& Yaacob, M. (2020). Dimensions of eWOM credibility on the online purchasing activities among consumers through social media. Jurnal Komunikasi: Malaysian Journal of Communication vol 36 (3), 335-352 https://doi.org/10.17576/JKMJC-2020-3603-21.

Connoly, B. (2017, December 5). Why consumers follow, listen to, and trust influencers. Retrieved June 27, 2019, from Olapic: https://www.olapic. com/resources/consumers-follow-listen-trustinfluencers_article/

Febriani, Z., \& Ranakusuma, O. I. (2020). Perilaku online beresiko remaja: Hubungannya dengan kualitas hidup dan mediasi orang tua. Jurnal Psikogenesis, 8(1). 89-100.

Festi, R., \& Quandt, T. (2020). Cyberbullying, online addiction, and sexting. In M. N. Potenza, K. Faust, \& D. Faust, The oxford handbook of digital technologies and mental health (pp. 259-274). Oxford University Press.

Fitriyah, L. (2016). Eksperimentasi sebagai pintu perilaku beresiko pada remaja. Seminar ASEAN 2nd Psychology 83 Humanity (pp. 198-203). Psychology Forum UMM.

Handayani, T. K. (2011). Pembuatan animasi 3D organ reproduksi manusia untuk meningkatkan pemahaman remaja dalam penyuluhan kesehatan reproduksi remaja. Skripsi. UIN Syarif Hidayatullah.

Hidayangsih, P. S. (2014). Perilaku berisiko dan permasalahan kesehatan reproduksi pada remaja. Indonesian Journal of Reproductive Health, 5(2), 89-101.

Jin, S. V., Muqaddam, A., \& Ryu, E. (2019). Instafamous and social media influencer marketing. Marketing Intelligence Eु Planning, 37(5), 567-579. https://doi.org/10.1108/MIP-09-2018-0375.

Karouw, e. E., Worang, F. G., \& Pandowo, M. H. (2019). Millennial trust through endorser credibility on local influencer endorsement on Instagram. JURNAL EMBA: JURNAL RISET EKONOMI, MANAJEMEN, BISNIS DAN AKUNTANSI, 7(3), 3818-3827.

Kasih, A. P. (2020, July 8). Pakar Unpad: Angka Pernikahan Dini Melonjak Selama Pandemi. Retrieved October 10, 2020, from Kompas.com: https:// edukasi.kompas.com/read/2020/07/08/131828971/pakar-unpadangka-pernikahan-dini-melonjak-selama-pandemi?page $=$ all 
KSR PMI Unhas. (2017). Fenomena Seks Bebas pada Kalangan Remaja di Kota Makassar. Diakses 15 Juli 2020 dari ksrpmiunhas.or.id: https://www. ksrpmiunhas.or.id/2017/11/fenomena-seks-bebas-pada-kalangan.html

Mulya, A. P., Lukman, M., \& Yani, D. I. (2020). Correlation of media and parents role to adolescent sexual behavior in SMA Bandung. Journal Nursing Care, 3(3). 191-198.

Nelissen, S., Beullens, K., Lemal, M., \& Bulck, J. V. (2015). Media use, cancer knowledge, and premarital relationship style choices: A cross-sectional analysis. European Journal of Public Health, March, 1-5 DOI: 10.1093/ eurpub/ckv018.

Prajagopta, D. (2019). Gambaran pengetahuan, sikap, dan perilaku beresiko terhadap infeksi menular seksual (IMS) pada anak jalanan di Kota Medan. Universitas Sumatera Utara.

Pratomo, Y., \& Yusuf, O. (2019, Mei 16). APJII: Jumlah Pengguna Internet di Indonesia tembus 171 Juta Jiwa. Retrieved Juni 26, 2019, from Kompas. com: https://tekno.kompas.com/read/2019/06/16/03260037/apjiijumlah-pengguna-internet-diindonesia-tembus-171-juta-jiwa

Rai, R., \& Tripathi, S. (2020). Consumer buying psychology and brand perception: Influence of word of mouth communication. Journal of Content, Community, and Communication. 12. 159-168. DOI: 10.31620/ JCCC.12.20/15

Rizal, M. N. (2017, November 24). Menghadapi Era Disrupsi. Retrieved Juni 27, 2019, from Republika: https://www.republika.co.id/berita/jurnalismewarga/wacana/17/11/24/ozw649440-menghadapi-era-disrupsi

Unicef, PUSKAPA, Bappenas, \& BPS. (2020). Pencegahan perkawinan anak: Percepatan yang tidak bisa ditunda. UNICEF \& PUSKAPA.

Vannucci, A., G. Simpson, E., Gagnon, S., \& Ohannessian, C. M. (2020). Social media use and risky behaviors in adolescents: A meta-analysis. Journal of Adolescence, 79, 258-274.

Waheed, M. (2019). Online threats and risky behavior from the perspective of Malaysian youths. SEARCH 11(2), 57-71

we are social \& Hootsuite. (2020, February 18). Digital 2020. (S. Kemp, Ed.) Retrieved October 10, 2020, from Datareportal: https://datareportal. $\mathrm{com} /$ reports/digital-2020-indonesia 
Investigating vertical social media impact through influencer on risky sexual ... (Raidah Intizar Yusuf)

Wed, E. N. (2020, August 13). Akibat Pergaulan Bebas Ratusan Remaja "Terpaksa" Menikah. Retrieved October 10, 2020, from news.okezone.com: https:// news.okezone.com/read/2020/08/13/340/2261628/akibat-pergaulanbebas-ratusan-remaja-terpaksa-menikah

Zhang, Y., Lin, Y., \& Goh, K. H. (2018). Impact of online influencer endorsement on product sales: Quantifying value of online. TwentySecond Pacific Asia Conference on Information Systems, Japan 2018 (p. 201). PACIS 2018 Proceedings. 
Informasi, Vol. 51. No. 2. (2021), 327-344 